\title{
Mechanism of resistance and presence of different resistance genes to Ramularia areola in two cotton genotypes
}

\author{
Carla Zandoná ${ }^{1}$, Tanara G. Novaes ${ }^{1}$, Maria Paula Nunes ${ }^{1}$, Wilson P. Almeida ${ }^{1}$, Paulo H. Aguiar ${ }^{2}$, Camilo L. \\ Morello $^{3}$, Ivan Shuster ${ }^{4}$ \& Yeshwant R. Mehta ${ }^{1}$ \\ ${ }^{1}$ Instituto Agronômico do Paraná (IAPAR), 86047-902, Londrina, PR, Brazil; ${ }^{2}$ Fundaçao MT, 78750-000, Rondonópolis, MT, \\ Brazil; ${ }^{3}$ Embrapa Algodão, 58428-095, Campina Grande, PB, Brazil; ${ }^{4}$ Cooperativa Central de Pesquisa Agrícola (Coodetec), \\ Cx. Postal 301, 85813-450, Cascavel, PR, Brazil
}

Author for correspondence: Yeshwant R. Mehta, e-mail: yrmehta@iapar.br

\begin{abstract}
Earlier studies showed that the resistance of cotton genotype FMT 02102996 to Ramularia areola is governed by one dominant gene. More recently, the resistance of another genotype CNPA BA 2003-2059 to $R$. areola was detected under field and glasshouse conditions. Present investigation was conducted to verify the mechanism of resistance of the genotype CNPA BA 2003-2059 and to find out if the resistance of these two genotypes is governed by the same or by different genes. Segregating plant populations derived from the cross between the resistant genotype CNPA BA 2003-2059 and the susceptible genotype FMT 701, the back cross populations, as well as those derived from the cross between the two resistant genotypes were evaluated for disease severity by artificial inoculations under glasshouse conditions. The ratio of plants segregating for resistance and susceptibility was studied by $\chi^{2}$ test. The results indicated that the resistance to $R$. areola in genotype CNPA BA 2003-2059 is governed by one dominant gene and that the resistance in each one of the resistant genotypes is governed by a different dominant gene. These results may assist the local breeding programs aimed at pyramiding resistance genes to this pathogen and may form the basis for genetic mapping of resistance genes.
\end{abstract}

Key words: Gossypium hirsutum, genetics, inheritance of resistance.

\section{RESUMO}

Mecanismo de resistência e presença de genes diferentes de resistência a Ramularia areola em dois genótipos de algodoeiro A mancha-de-ramulária, causada por Ramularia areola, é uma das doenças de importância econômica para o Brasil. Estudos anteriores demonstraram que a herança da resistência do genótipo FMT 02102996 a $R$. areola é governada por um gene dominante. Recentemente, a resistência do genótipo CNPA BA 2003-2059 a este patógeno foi verificada em casa de vegetação e no campo. O presente estudo foi realizado para verificar o mecanismo de resistência deste genótipo e verificar se os genes de resistência dos dois genótipos resistentes são os mesmos. Foram avaliadas populações segregantes derivadas do cruzamento entre o genótipo resistente CNPA BA 2003-2059 e o genótipo suscetível FMT 701, dos retrocruzamentos, e também do cruzamento entre os dois genótipos resistentes. As plantas foram classificadas como resistentes ou suscetíveis por meio de inoculação artificial. Com base nos resultados, constatou-se que a resistência do genótipo CNPA BA 2003-2059 é condicionada por um gene dominante e que os dois genótipos possuem um gene diferente de resistência. Estes resultados podem auxiliar o planejamento dos programas de melhoramento do algodoeiro visando piramidar genes de resistência a $R$. areola em novas cultivares, ao mesmo tempo constituindo informação básica para o início de trabalhos de mapeamento genético deste gene de resistência.

Palavras-chave: Gossypium hirsutum, genética, herança de resistência.

\section{INTRODUCTION}

Ramularia leaf spot caused by Ramularia areola is a very destructive disease of cotton (Gossypium hirsutum) in Brazil. The initial symptoms of the disease are characterized as small angular necrotic lesions of 3-4 mm. At an advanced stage the lesions coalesce and become necrotic with severe chlorosis, causing premature leaf abscission and consequently affecting the production of cotton. In the Cerrado region of Brazil the yield losses caused by this disease are estimated to be around $30 \%$, but in severe cases they can be up to $75 \%$ in the State of Mato Grosso, especially in highly susceptible cultivars. In countries like India and Madagascar yield losses of over $60 \%$ are recorded (Cauqui \& Sement, 1973; Shivankar \& Wangikar, 1992; Cia et al., 1999; Utimada et al., 2003; Novaes et al., 2011). At present the disease is partially controlled by $4-5$ applications of fungicide in Brazil. Although the disease can be controlled by the use of resistant cultivars, such cultivars are not yet available for commercial cultivation.

While studies about inheritance of resistance to some important cotton pathogens are reported (Wallace \& El-Zik, 1989; Mehta \& Arias, 2001; Zandona et al., 2005, 2006; Popum et al., 2007; Novaes et al., 2011), relatively little 
information is available about the mechanism of resistance of cotton cultivars to $R$. areola (Lucena et al., 2007; Novaes et al., 2011). Earlier studies showed that the resistance to $R$. areola of the genotype FMT 02102996 originated from the cross between the cultivar Fibermax 966 and one of the breeding lines of the Fundação Mato Grosso-FMT is governed by one dominant gene (Novaes et al., 2011). More recently, the resistance of another genotype CNPA BA 2003-2059 (one of the breeding lines) to $R$. areola was detected under field and glasshouse conditions. Resistance of some other genotypes was also detected under field conditions; however, their resistance was not found to be consistent presumably because of the genetic variability among the pathogen population occurring across the cotton growing regions of Brazil (Cia et al., 1999). So far, adequate information is not available about the phenotypic or genotypic variability within the pathogen population. Knowledge about different sources of resistance would help pyramiding resistance genes in agronomically desirable cultivars of G. hirsutum.

The objectives of the present investigation were to: (i) verify the mechanism of resistance of the genotype CNPA BA 2003-2059, and (ii) determine if the resistance of the two genotypes (FMT 02102996 and CNPA BA 2003-2059) is governed by the same or by different genes, in order to assist breeding programs aimed at developing cotton cultivars resistant to $R$. areola.

\section{MATERIAL AND METHODS}

\section{Seed material and crosses}

Genetic seed of the parental population was obtained from Camilo de Lelis Morello (Embrapa Algodão, Campina Grande, PB, Brazil) and Paulo Aguiar (Fundação MT, Rondonópolis, MT, Brazil). Plants of both genotypes were segregating for resistance to $R$. areola under glasshouse inoculations. For this reason, plants of each parent were inoculated during two successive generations to purify and to confirm their resistance and susceptibility reactions. Before crosses were made seeds derived after second generation by selfing a single plant of each one of the genotypes were further used to make sure the homozygocity of the parental material. Plants were grown in $30-\mathrm{mm}$ pots containing a mixture of sterilized soil, sand and compost in equal proportions, under glasshouse conditions.

Seeds of the F1, F2, populations of the cross between the resistant genotype CNPA BA 2003-2059 and the susceptible genotype FMT 701, as well as their backcross populations derived from crosses between F1 and the resistant (RC1F1r) and susceptible genotype (RC1F1s), were obtained. F1 and F2 populations derived from the cross between the two resistant genotypes FMT 02102996 and CNPA BA 2003-2059 were also obtained. Although several plants were used for crossing and selfing, hybrid seeds originated from a single plant were used in all the cases to evaluate subsequent segregating populations.
Seeds of the parental genotypes along with the segregating populations were simultaneously multiplied at all stages under glasshouse conditions to avoid effect of age of the seed in the expression of disease symptoms (Mehta et al., 2001; Mehta \& Arias, 2002).

\section{Inoculation}

The monosporic aggressive isolate 44 of $R$. areola from the collection of IAPAR was used in all the inoculations. Fungal isolate was multiplied for 7-10 days on V8-juice agar, the conidia were scraped from the sporulating cultures, the conidial suspension of the inoculum was adjusted to $10^{4}$ conidia/mL, and a few drops of Tween 20 was added to the inoculum. Twenty-five days old plants were inoculated using a hand sprayer and approximately an equal amount of inoculum per plant was sprayed. Soon after inoculation the plants were incubated in a growth chamber in dark adjusted to $21^{\circ} \mathrm{C}$ and relative humidity of approximately $100 \%$ for 48 h. After this period the plants were transferred to glasshouse bench and randomized. The glasshouse temperatures varied between 20 and $30^{\circ} \mathrm{C}$.

\section{Disease severity assessment}

The disease severity on the leaves was assessed $30 \mathrm{~d}$ after inoculation using a visual scale between 0 and $100 \%$ of the leaf area infected (LAI), in three categories in which: 1 = small necrotic spots without chlorosis covering $0-1 \%$ LAI; 2 = necrotic spots without chlorosis covering $<5 \%$ LAI; 3 = typical angular spots with chlorosis covering $>5 \%$ LAI. Categories 1 and 2 were considered resistance reaction and category 3 susceptible reaction (Novaes et al., 2011). The results were analyzed using the chi-square test.

\section{RESULTS AND DISCUSSION}

After purification of the parental seed material, all plants of the genotypes FMT 02102996 and CNPA BA 2003-2059 showed complete resistance to the pathogen, whereas all plants of the genotype FMT 701 showed high susceptibility (Figure 1). Plants of the F1 generation of the cross FMT 701 x CNPA BA 2003-2059 showed complete resistance whereas using a relatively larger population, of the F2 plants (406 plants), the F2 population segregated to 306 plants resistant and 100 plants susceptible, thus demonstrating a segregation ratio of $3 \mathrm{R}: 1 \mathrm{~S}$, conditioning resistance of genotype CNPA BA-2003-2059 to $R$. areola. RC1F1s populations segregated for phenotypic ratio of $1: 1$, whereas plants of $\mathrm{RC} 1 \mathrm{~F} 1_{\mathrm{R}}$ generation were all resistant, once again confirming the presence of one dominant gene in the genotype CNPA BA-2003-2059 (Table 1). Similar results were obtained by Novaes et al. (2011) showing monogenic resistance of genotype FMT 02102996.

Dominance for resistance was complete in all the plants of the resistant genotypes CNPA BA 2003-2059 and FMT 02102996. Plants of the F1 generation of the cross between these two resistant genotypes were all resistant. 

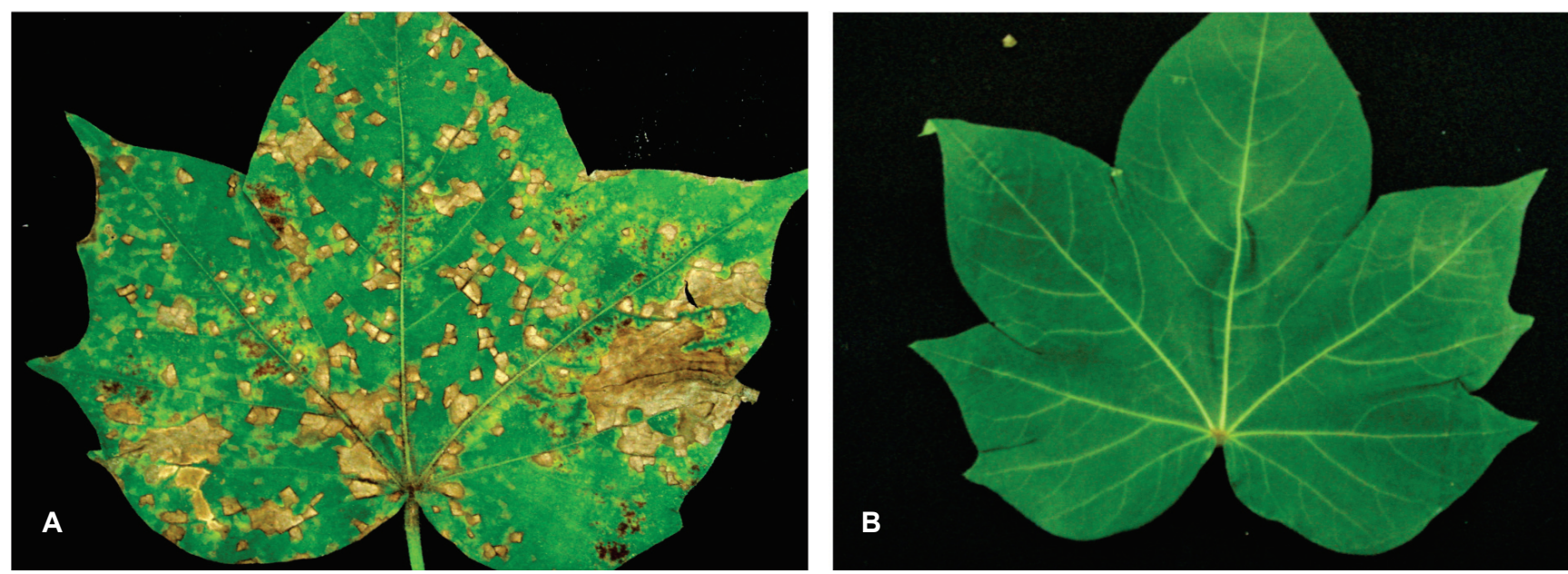

FIGURE 1 - A. Typical angular spot symptoms of Ramularia leaf spot on leaf of the susceptible cotton genotype FMT 701; B. Absence of symptoms of the disease on leaf of the resistant genotype CNPA BA 2003-2059, $30 \mathrm{~d}$ after artificial inoculation under glasshouse conditions using an aggressive isolate of Ramularia areola.

TABLE 1 - Mechanism of resistance of the cotton genotype CNPA BA- 2003-2059 to Ramularia areola verified by chi-square test for segregation pattern between resistant and susceptible plants of the F2 generation as well as of the backcross populations, involving cross with a susceptible and resistant parentes, by artificial inoculation under glasshouse conditions

\begin{tabular}{|c|c|c|c|c|c|c|c|c|}
\hline \multirow{3}{*}{$\begin{array}{l}\text { Progenitor and } \\
\text { segregating } \\
\text { population }\end{array}$} & \multirow{3}{*}{$\begin{array}{l}\text { Foliar } \\
\text { reaction* }\end{array}$} & \multicolumn{6}{|c|}{ Number of individuals in each category of infection* } & \multirow[t]{3}{*}{$\mathbf{X} 2$} \\
\hline & & \multirow{2}{*}{$\begin{array}{l}\text { Total number of } \\
\text { individuals }\end{array}$} & \multirow{2}{*}{$\begin{array}{l}\text { Therotical } \\
\text { ratio (R:S) }\end{array}$} & \multicolumn{2}{|c|}{ Observed } & \multicolumn{2}{|c|}{ Expected } & \\
\hline & & & & $\mathbf{R}$ & $\mathbf{S}$ & $\mathbf{R}$ & $\mathbf{S}$ & \\
\hline FMT 701 & $\mathrm{~S}$ & 15 & $0: 1$ & 0 & 15 & 0 & 15 & -- \\
\hline $\begin{array}{l}\text { CNPA-BA } 2003 \text { - } \\
2059\end{array}$ & $\mathrm{R}$ & 15 & $1: 0$ & 15 & 0 & 15 & 0 & -- \\
\hline F1 & $\mathrm{R}$ & 35 & $1: 0$ & 35 & 0 & 35 & 0 & \\
\hline F2 & $\mathrm{R} / \mathrm{S}$ & 406 & $3: 1$ & 306 & 100 & 304.5 & 101.5 & $\begin{array}{c}0.03 \\
(\mathrm{P}=86.35)\end{array}$ \\
\hline RC1F1R & $\mathrm{R}$ & 48 & $1: 0$ & 48 & 0 & 48 & 0 & \\
\hline $\mathrm{RC} 1 \mathrm{~F} 1 \mathrm{~S}$ & $\mathrm{R} / \mathrm{S}$ & 48 & $1: 1$ & 27 & 21 & 24 & 24 & NS \\
\hline
\end{tabular}

*Disease severity scale between 0 and 100\% of the leaf area infected (LAI): 1 = small necrotic spots without chlorosis, covering $0-1 \%$ LAI; $2=$ necrotic spots without chlorosis, covering $<5 \%$ LAI; 3 = typical angular spots with chlorosis, covering $>5 \%$ LAI. Categories 1 and 2 were considered as resistant reactions and category 3 as susceptibility reaction. NS $=$ non-significant $(\mathrm{P}=0.5)$.

Also using a relatively larger F2 population of this cross (348 plants), a segregation ratio of $15 \mathrm{R}: 1 \mathrm{~S}$ was verified where the difference between the observed and expected plants segregating for resistance and susceptibility was not significant according to the chi-square test for goodness of fit (Table 2). If both resistant genotypes had the same dominant gene for resistance, then all the plants of the F2 population would be resistant and no segregation would be observed.

Contrary to our findings and to those reported by Novaes et al. (2011), Lucena et al. (2007) reported a polygenic mode of resistance to $R$. areola in the cotton genotype VH84602 - an advanced breeding line originated from Africa belonging to Gossypium barbadense. Being polygenic in nature it would not be easy to transfer the resistance of $G$. barbadense to G. hirsutum cultivars. Besides, the genotype
VH8-4602 does not have good combining ability (W.P. de Almeida, personal communication).

The results of the present investigation indicated that resistance to $R$. areola in each one of the resistant genotypes is governed by a different dominant gene. These results may assist the strategies of breeding programs aimed at pyramiding resistance genes to $R$. areola in new and agronomically desirable cultivars and may form the basis for genetic mapping of resistance genes to be further used in the marker assisted selection programs. For pyramiding resistance genes in a commercial cotton cultivar it is advisable to identify more resistance genes against other field strains of $R$. areola occurring in major cotton growing areas of Brazil.

Considering that the inheritance of resistance in the two genotypes studied in the present investigation is simple, 
TABLE 2 - Evidence of the presence of different resistance genes to Ramularia areola in two cotton genotypes as verified by chi-square test of the segregating pattern for resistance and susceptibility, by artificial inoculation of the progenitors and the F2 population involving the cross between the genotypes CNPA BA-2003-2059 and FMT 02102996, under glasshouse conditions

\begin{tabular}{|c|c|c|c|c|c|c|c|c|}
\hline \multirow{3}{*}{$\begin{array}{l}\text { Progenitor and } \\
\text { segregating } \\
\text { population }\end{array}$} & \multirow{3}{*}{$\begin{array}{c}\text { Foliar } \\
\text { reaction* }\end{array}$} & \multicolumn{6}{|c|}{ Number of individuals in each category of infection* } & \multirow[t]{3}{*}{$\mathbf{X} 2$} \\
\hline & & \multirow{2}{*}{$\begin{array}{l}\text { Total number of } \\
\text { individuals }\end{array}$} & \multirow{2}{*}{$\begin{array}{l}\text { Therotical } \\
\text { ratio (R:S) }\end{array}$} & \multicolumn{2}{|c|}{ Observed } & \multicolumn{2}{|c|}{ Expected } & \\
\hline & & & & $\mathbf{R}$ & $\mathbf{S}$ & $\mathbf{R}$ & $\mathbf{S}$ & \\
\hline FMT $02102996 * *$ & $\mathrm{R}$ & 26 & $1: 0$ & 26 & 0 & 26 & 0 & -- \\
\hline $\begin{array}{l}\text { CNPA-BA } 2003- \\
2059\end{array}$ & $\mathrm{R}$ & 13 & $1: 0$ & 13 & 0 & 13 & 0 & -- \\
\hline F1 & $\mathrm{R}$ & 30 & $1: 0$ & 30 & 0 & 30 & 0 & \\
\hline $\mathrm{F} 2$ & $\mathrm{R} / \mathrm{S}$ & 348 & $15: 1$ & 319 & 29 & 326.24 & 21.75 & $\begin{array}{c}2.58 \\
(\mathrm{P}=10.84) \\
\mathrm{NS}\end{array}$ \\
\hline
\end{tabular}

*Disease severity scale between 0 and $100 \%$ of the leaf area infected (LAI): 1 = small necrotic spots without chlorosis, covering $0-1 \%$ LAI; $2=$ necrotic spots without chlorosis, covering $<5 \%$ LAI; $3=$ typical angular spots with chlorosis, covering $>5 \%$ LAI. Categories 1 and 2 were considered as resistant reactions and category 3 as susceptible reaction. NS $=$ non-significant $(\mathrm{P}=0.5)$. ** Resistance of this genotype is governed by a single dominant gene (Novaes et al., 2011).

back crossing programs can also be used to convert elite susceptible cultivars to resistant ones. The use of resistant cultivars would avoid the indiscriminate use of fungicides, would reduce the cost of cultivation and at the same time would contribute towards the sustainable and eco-friendly cotton production in Brazil. There is a major concern among the cotton growers of Brazil that the heavy and constant use of fungicides besides creating several problems, in a longer run may not be cost effective.

\section{ACKNOWLEDGEMENTS}

Thanks are due to technical assistance provided by Vieira C.B. and Juliana Barbosa.

\section{REFERENCES}

Cauquil JS, Sement GL (1973) Faux mildiou du cotonnier (Ramularia areola Atk.) dans le sud-ouest de Madagascar. Coton et Fibres Tropicales 28:279-286.

Cia E, Fuzzatto MG, Chiavegato EJ, Farias FJC, Araújo AE (1999) Desempenho de cultivares e linhagens de algodoeiro diante da incidência de Ramularia. In: II Congresso Brasileiro de Algodão, Resumos... Ribeirão Preto SP. Embrapa Algodão.

Lucena VS, Hoffman LV, Suassuna ND, Giband M, Barroso PAV, Almeida VC, Coutinho M (2007) Caracterização da genética de resistência à mancha-de-ramulária nas cultivares Guazuncho-2 e VH8-4602. In: VI Congresso Brasileiro de Algodão, Resumos... Uberlândia MG. Embrapa Algodão.

Mehta YR, Arias CAA (2002) Herança da resistência a Stemphylium solani e insensibilidade a sua fitotoxina em cultivares de algodoeiro. Fitopatologia Brasileira 26:761-765.

Mehta YR, Arias CAA, Toledo JFF (2001) Inheritance of resistance to Magnaporthe gresea in wheat. Summa Phytopathologica 27:300-304.

Novaes TG, Almeida WP, Schuster I, Mehta YR (2011) Herança de resistência do algodoeiro a Ramularia areola. Summa Phytopathologica 37:150-152.

Pupim OJ, Schuster I, Pires EBJ, Silvie P, Chitarra LG, Hoffmann BPAV (2007) Herança da resistência do algodoeiro à doença azul. In: VI Congresso Brasileiro de Algodão, Resumos... Uberlândia MG. Embrapa Algodão.

Shivankar SK, Wangikar PD (1992) Estimation of crop losses due to grey mildew disease of cotton caused by Ramularia areola. Indian Phytopathology 45:74-76.

Utiamada CM, Lopes JC, Sato LN, Roim FLB, Kajihara L, Occhiena EM (2003) Controle químico da ramularia (Ramularia areola) e ferrugem (Phakospora gossypii) na cultura do algodoeiro. In: IV Congresso Brasileiro de Algodão, Resumos... Goiânia GO. Embrapa Algodão.

Wallace TP, El-Zik KM (1989) Inheritance of resistance in three cotton cultivars to the HV1 isolate of bacterial blight. Crop Science 29:1114-1119.

Zandoná C, Mehta YR, Schuster I, Alves PFR, Bomfeti CA, Bibanco, KRP, Silva RB, Lopes LP (2005) Mecanismo genético de resistência em três cultivares de algodoeiro a Xanthomonas axonopodis pv. malvacearum. Fitopatologia Brasileira 30:647649.

Zandoná C, Novaes TG, Mehta YR, Schuster I, Teixeira EA, Cunha EA (2006) Herança de resistência a Colletotrichum gossypii var. cephalosporioides em algodoeiro brasileiro. Fitopatologia Brasileira 31:76-78.

TPP 323 - Received 25 May 2011- Accepted 16 April 2012 Section Editor: Luis Eduardo Aranha Camargo 